\title{
Chemical profiling of selected Ayurveda formulations recommended for COVID-19
}

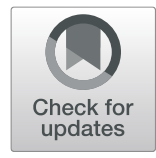

\author{
Sulaiman C. T. ${ }^{*}$ (D), Deepak M. ${ }^{1}$, Ramesh P. R. ${ }^{2}$, Mahesh K. ${ }^{2}$, Anandan E. M. ${ }^{3}$ and Indira Balachandran ${ }^{1}$
}

\begin{abstract}
Background: The novel coronavirus disease 2019 (COVID-19), caused by the severe acute respiratory syndrome coronavirus-2 (SARS-CoV-2), is the global health concern since December 2019. It has become a big challenge for the researchers to find a solution for this newly evolved pandemic. In Ayurveda point of view, COVID-19 is a Janapadodhwamsa vikara (epidemic disease), a situation where the environment-air, water, land, and seasons-is vitiated, causing a simultaneous manifestation of a disease among large populations. The aim of this study is to identify the active compounds of selected Ayurveda medicines recommended for COVID-19.

Results: The selected preparations are traditionally recommended for the management of various kinds of fever including the infectious ones and to enhance the immunity. HPTLC analysis of the same showed presence of many active molecules like umbelliferone, scopoletin, caffeic acid, ferulic acid, gallic acid, piperine, curcumin, berberine, and palmatine.
\end{abstract}

Conclusion: The study provided valuable scientific data regarding the active ingredients of the selected medicines with proven therapeutic potentials like anti-viral, immunomodulatory, and anti-inflammatory activities.

Keywords: COVID-19, Ayurveda, Indukantham Kwatham, Vilvadi Gulika, Mukkamukkatuvadi Gulika, HPTLC

\section{Background}

COVID-19 has emerged as the most dangerous global pandemic threat since its outbreak during December 2019 in Wuhan, China. As of September 4, 2020, the World Health Organization (WHO) has reported more than 26 million confirmed cases and 8.6 lakhs deaths worldwide and it has spread to 216 countries, areas, or territories (https://www.who.int/emergencies/diseases/ novel-coronavirus-2019). Now, it is a big challenge for the researchers and health professionals to find out a solution for this deadly viral infection. COVID-19 is a viral infection that has been known to have the fastest frequency of replication in its positive strand resulting in the quick development of new progeny viral cells inside the host cells. SARS-CoV-2 is a single-stranded RNA pathogen, which is characterized by a high mutation rate

\footnotetext{
*Correspondence: slmnct@gmail.com; sulaimanct@aryavaidyasala.com ${ }^{1}$ Phytochemistry Division, Centre for Medicinal Plants Research, Arya Vaidya Sala, Kottakkal, Malappuram, Kerala 676503, India

Full list of author information is available at the end of the article
}

[1, 2]. In Ayurveda point of view, COVID-19 is a Janapadodhwamsa vikara (epidemic disease), a situation where the environment-air, water, land, and seasonsis vitiated, causing a simultaneous manifestation of a disease among large populations [3].

Medicinal plants have been used as a treatment and defensive strategy for several infectious diseases since ancient times. The benefit of using these herbs in viral respiratory infections is to build immune-stimulating and inflammation-modulating effects to prevent severe life-threatening conditions. Holistic approach of Ayurveda focuses on prevention of diseases through lifestyle modification, dietary management, prophylactic interventions for improving the immunity, and managing the symptoms using herbal preparations. Medicinal plants have been reported to have anti-viral activity and many species such as Aegle marmelos, Andrographis paniculata, Acacia nilotica, Ocimum tenuiflorum, Piper nigrum, Solanum nigrum, and Terminalia chebula have been scientifically proved for their anti-viral properties [4-6]. 
Ayurveda medicines were recommended by the Ministry of AYUSH, Government of India to enhance the immunity and to prevent the severe conditions of Cov-2 infection. Detailed guidelines have been published by the AYUSH Ministry regarding the management of COVID-19 (https:// www.ayush.gov.in/ayush-guidelines.html). About 80\% of COVID-19 cases are with mild symptoms requiring only primary medical care. Ayurveda medicines are advised to patients with mild symptoms and those under surveillance which addresses the therapeutic province within an integrative model of care [7]. The present study was focused on the identification of active ingredients of certain Ayurveda medicines such as Indukantham Kwatham (IK), Vilvadi Gulika (VG), and Mukkamukkatuvadi Gulika (MMG) in which the ingredient plants have been reported to possess immunomodulatory and anti-viral properties.

Indukantham Kwatham is a polyherbal tablet prepared out of specific parts of different medicinal plants such as Holoptelea integrifolia, Cedrus deodara, Gmelina arborea, Aegle marmelos, Stereospermum colais, Oroxylum indicum, Premna corymbosa, Desmodium gangeticum, Pseudarthria viscida, Solanum anguivi, Solanum virginianum, Tribulus terrestris, Piper longum, Piper mullesua, Plumbago zeylanica, and Zingiber officinale. It

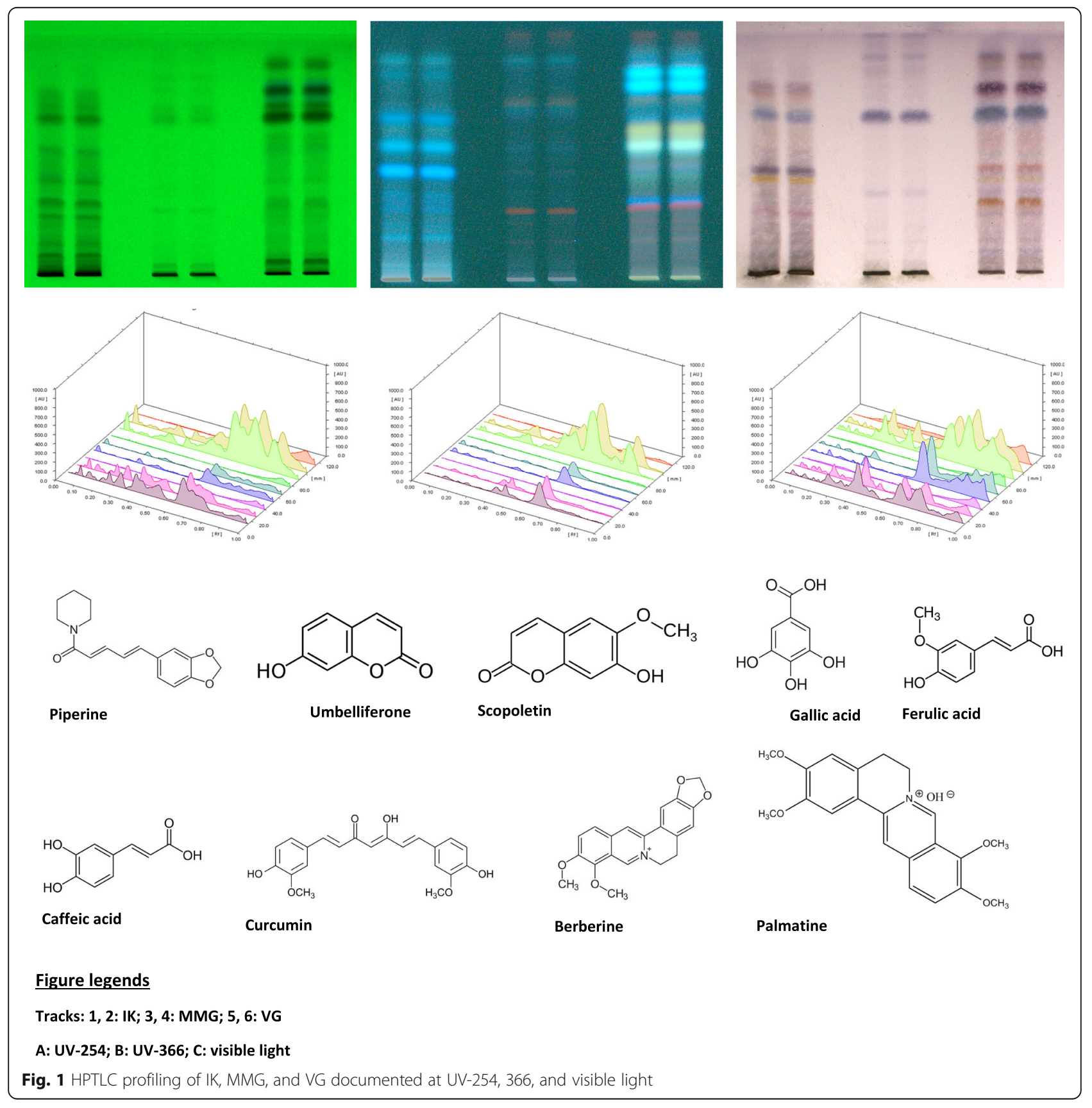


is generally used for the treatment of intermittent fever and fatigue and to enhance the resistance power [8]. Vilvadi Gulika is prepared using different parts of the various medicinal plants such as Aegle marmelos, Ocimum tenuiiflorum, Pongamia pinnata, Veleriana jatamansi, Cedrus deodara, Terminalia chebula, Phyllanthus emblica, Terminalia bellirica, Zingiber officinale, Piper nigrum, Piper longum, Curcuma longa, and Berberis aristata. The ingredient plants of Mukkamukkatuvadi Gulika are Terminalia chebula, Phyllanthus emblica, Terminalia bellirica, Zingiber officinale, Piper nigrum, Piper longum, Cuminum cyminum, Nigella sativa, Acorus calamus, Swertia chirata, Cinnamomum camphora, Myristica fragrans, Aloe vera, Syzygium aromaticum, Allium sativum, Piper cubeba, Saussurea costus, Cinnamomum verum, Ferula assa-foetida, Trchyspermum roxburghianum, and Vitex negundo [8].

\section{Methods}

\subsection{Chemicals and reagents}

Chemicals such as toluene (CN: IE5F650118), ethyl acetate (CN: ID5F650128), and methanol (CN: SA5P650021) were procured from Merck India.

\subsection{Sample preparation}

The selected medicines were obtained from the Product Development Department of the Institute. Two grams each of IK (Batch No. 198339), VG (Batch No. 193083), and MMG (Batch No. 194967) were sonicated with chromatographic grade methanol in an ultra-sound bath (Labnet Scientific, India) for $20 \mathrm{~min}$. It was then filtered through a membrane filter $(0.45 \mu \mathrm{m})$ and kept under the refrigerator until HPTLC analysis.

\subsection{Instruments and general chromatographic conditions} HPTLC analysis was carried out by the CAMAG HPTL C system (Switzerland). Samples were applied using CAMAG ATS 4 auto sampler on aluminum backed precoated silica gel $60 \mathrm{~F}_{254}$ HPTLC plate (Merck India). Mobile phase was optimized as toluene, ethyl acetate, and methanol in the ratio of 7:3:1. The chromatogram was developed in a saturated Twin Trough chromatographic chamber (Camag, Switzerland) and was visualized under UV-chamber (254 and $366 \mathrm{~nm}$ ) and in visible light after derivatizing with anisaldehyde sulfuric acid reagent followed by heating at $105^{\circ} \mathrm{C}$ for $5 \mathrm{~min}$.

\section{Results}

Rapid chromatographic method has been developed for the chemical fingerprinting of selected medicines by modern high-performance thin-layer chromatography. The optimized mobile phase provided good resolution under various documentation systems such as UV-254, 366, and visible light. Chromatogram and 3D-illustrated display are presented in Fig. 1. HPTLC analysis showed presence of various compounds belonging to different groups of phytochemicals such as alkaloids, coumarins, and phenolics. Structural identification was confirmed with matching $R_{\mathrm{f}}$ of standard compounds. The compounds identified from the tested formulations are given in Table 1.

Coumarins such as umbelliferone and scopoletin are detected in all the three selected medicines and these are the plant coumarins reported from many medicinal plants. Phenolic compounds like caffeic acid and ferulic acid are found in both IK and VG. Gallic acid was identified from all the three selected medicines and has been reported from many ingredient plants. VG showed the presence of alkaloids such as curcumin, berberine, and palmatine which might have extracted from its ingredient plants like Piper nigrum, Piper longum, Curcuma longa, and Berberis aristata.

\section{Discussion}

Bioactive compounds from natural products are attractive candidates for drug development. Numerous medicinal plants have been reported to possess various therapeutic properties including anti-viral, anti-inflammatory, and immunomodulatory activities. The chemical profiling of three selected medicines showed the presence of various biologically active compounds belonging to different classes of phytochemicals such as alkaloids, phenolics, and coumarins. Coumarins such as umbelliferone and scopoletin were found to be common for all the selected samples. Naturally occurring coumarins have been reported to possess diverse biological and pharmacological properties such as anti-viral, anti-coagulant, anti-bacterial, anti-fungal, antiprotozoal, insecticidal, fungicide, anti-mycobacterial, antimutagenic, anti-amnesic, and anti-inflammatory activities $[9,10]$. There are numerous evidences for the inhibitory role of coumarins against infection of various viruses such as HIV, influenza, enterovirus 71, and coxsackievirus A16. The mechanisms involve either inhibition of proteins essential for viral entry, replication, and infection or regulation of

Table 1 Compounds identified from IK, MMG, and VG by HPTLC analysis

\begin{tabular}{llll}
\hline SI. no. & Compounds & $\boldsymbol{R}_{\mathbf{f}}$ value & Present in \\
\hline 1 & Caffeic acid & 0.21 & IK, VG \\
2 & Palmatine & 0.33 & VG \\
3 & Ferulic acid & 0.37 & IK, VG \\
4 & Gallic acid & 0.43 & IK, VG, MMG \\
5 & Scopoletin & 0.44 & IK, VG, MMG \\
6 & Berberine & 0.45 & VG \\
7 & Umbelliferone & 0.57 & IK, VG, MMG \\
8 & Piperine & 0.71 & MMG \\
9 & Curcumin & 0.73 & VG \\
\hline
\end{tabular}


cellular pathways such as Akt-Mtor, NF-kB, and antioxidative pathways including NrF-2 [11].

Alkaloids such as piperine, curcumin, berberine, and palmatine were identified from the selected medicines. Piperine is detected from both IK and MMG and that might have come from the ingredient plant Piper nigrum. The immunomodulatory potential of piperine has been reported earlier [12]. Piperine was reported to inhibit proliferative response induced by lipopolysaccharide (LPS) and immunoglobulin $\alpha$-IgM antibody and resulted in inhibition of IgM antibody secretion and reduced expression of cluster of differentiation CD86 [13]. Another study by Lee et al. 2018 [14] demonstrated that piperine in combination with gamma-aminobutyric acid (GABA) mediated p38 and JNK MAPK activation, which increased EPO and EPO-R expression, resulting in upregulation of IL-10 and NF- $\mathrm{kB}$. Alkaloids like curcumin, berberine, and palmatine were identified from VG. The anti-viral effect of curcumin on Zika and chikungunya viruses has been well established [15]. The literature showed that curcumin mediates its anti-viral activity through various mechanisms. Curcumin has been reported to inhibit the Japanese encephalitis virus by dysregulated ubiquitin-proteasome system and an accumulation of ubiquitinated proteins [16]. Curcumin was also reported to inhibit various virus replications like Rift Valley fever virus and hepatitis $C$ virus [17, 18]. Moreover, curcumin was shown to impact HCV replication through binding and fusion [19] and similar results were reported in the case of ZIKV and CHIKV. HIV-1 integrase activity of curcumin was also reported previously [20]. Various pharmacological activities of berberine such as anti-oxidant, anti-bacterial, anti-inflammatory, anti-viral, nephroprotective, and cardioprotective have been reported earlier [21]. Anti-viral activity of berberine against human cytomegalovirus has been reported previously [22]. The immunomodulatory effect of berberine was validated in many previous literatures [23-25].

Currently, there are no available vaccines or specific medicines for the treatment of COVID-19. In light of the outbreak, various treatment modalities have been considered, including herbal medicine, which has been widely used during the past epidemic outbreaks, such as severe acute respiratory syndrome (SARS) and H1N1 influenza. The phytochemicals identified from IK, MMG, and VG are active molecules with potential biological properties such as anti-viral, anti-inflammatory, and immunomodulatory activities.

\section{Conclusion}

COVID-19 pandemic is a global challenge for human health, and researchers are urgently seeking medicine for it. Currently, the treatment options for COVID-19 are limited due to non-availability of vaccines or specific medicines. In this context, the search for traditional herbal medicine is also a viable strategy for COVID-19 management. The present study on selected Ayurveda medicines provided valuable scientific data regarding the active ingredients of the drugs tested with proven therapeutic potentials like anti-viral, immunomodulatory, and anti-inflammatory activities.

\section{Abbreviations \\ IK: Indukantham Kwatham; VG: Vilvadi Gulika; MMG: Mukkamukkatuvadi Gulika; HPTLC: High-performance thin-layer chromatography}

\section{Acknowledgements}

SCT sincerely thank Dr. Geetha S Pillai, Deputy Project Director, CMPR, Arya Vaidya Sala, Kottakkal, Kerala, India, for the valuable suggestions.

\section{Authors' contributions}

All authors have read and approved the manuscript. SCT: Designed and implemented the work, done the data analysis; DM: Carried out HPTLC analysis; RPR: Provided resources; MK: Contributed background data; AEM: Prepared the samples; IB: Supervision and edited the manuscript.

\section{Funding}

This work was funded by Navajbhai Ratan Tata Trust, Mumbai, India (Grand Number: RLC-PPP-AVS-20150930). The fund was used for required chemicals and reagents.

\section{Availability of data and materials}

The datasets used and/or analyzed during the current study are available from the corresponding author on reasonable request.

Ethics approval and consent to participate

Not applicable

Consent for publication

Not applicable

\section{Competing interests}

The authors declare that they have no competing interests.

\section{Author details}

${ }^{1}$ Phytochemistry Division, Centre for Medicinal Plants Research, Arya Vaidya Sala, Kottakkal, Malappuram, Kerala 676503, India. ${ }^{2}$ Clinical Research Department, Arya Vaidya Sala, Kottakkal, Kerala, India. ${ }^{3}$ Product Development Department, Arya Vaidya Sala, Kottakkal, Kerala, India.

Received: 12 August 2020 Accepted: 26 November 2020

Published online: 11 January 2021

\section{References}

1. Chitranshi N, Gupta VK, Rajput R, Godinez A, Pushpitha K, Shen T, Mirzaei M, You Y, Basavarajappa D, Gupta V, Graham SL (2020) Evolving geographic diversity in SARS-CoV2 and in silico analysis of replicating enzyme 3CLpro targeting repurposed drug candidates. J Transl Med 18:278

2. Chen H, Guo J, Wang C, Luo F, Yu X, Zhang W, Li J, Zhao D, Xu D, Gong Q (2020) Clinical characteristics and intrauterine vertical transmission potential of COVID-19 infection in nine pregnant women: a retrospective review of medical records. Lancet 395:809-815

3. Girija LT, Sivan N (2020) Ayurveda treatment of COVID-19/ SARS-CoV-2: a case report. J Ayu Int Med. https://doi.org/10.1016/j.jaim.2020.06.001

4. Venkateswaran PS, Millman I, Blumberg BS (1987) Effects of an extract from Phyllanthus niruri on hepatitis B and woodchuck hepatitis viruses: in vitro and in vivo studies. Proc Natl Acad Sci U S A 84:274-278

5. Hudson JB (1990) Antiviral compounds from plants. CRC Press, Boca Raton, Ann Arbor, Boston

6. Vellingiri B, Jayaramayya K, lyer M, Narayanasamy A, Govindasamy V, Giridharan B, Ganesan S, Venugopal A, Venkatesan D, Ganesan H, Rajagopalan K, Rahman PKSM, Cho SG, Kumar NS, Subramaniam MD (2020) 
COVID-19: a promising cure for the global panic. Sci Total Environ. https:// doi.org/10.1016/j.scitotenv.2020.138277

7. Rastogi S, Pandey DN, Singh RH (2020) COVID-19 pandemic: a pragmatic plan for Ayurveda intervention. J Ayurveda Integr Med. https://doi.org/10. 1016/j.jaim.2020.04.002

8. Kurup KV (2017) Sahasrayogam [Text book of 1000 Herbal formulations] Malayalam translation with Vaidya Priya Commentary. Sree Rama Vilasam Press and Book Depo, Kollam, pp 446-457

9. Karatas MO, Uslu H, Alici B, Gokce B, Gencer N, Arslan O (2016) Some coumarins and benzoxazinones as potent paraoxonase 1 inhibitors. J Enzyme Inhib Med Chem:1386-1391

10. Sulaiman CT, Deepak M, Sunil AR, Lijini KR, Balachandran I (2019) Characterization of coumarins from Ipomoea mauritiana Jacq by LC-APCIMS/MS analysis and evaluation of its anti-amnesic activity. Beni-Suef Univ J Basic Appl Sci https://doi.org/10.1186/s43088-019-0022-z

11. Mishra S, Pandey A, Manvati S (2020) Coumarin: an emerging antiviral agent. Heliyon. https://doi.org/10.1016/j.heliyon.2020.e03217

12. Bezerra DP, De Castro FO, Alves APNN, Pessoa C, De Moraes MO, Silveira ER, Lima MAS, Elmiro FJM, De Alencar NMN, Mesquita RO (2008) In vitro and in vivo antitumor effect of 5-FU combined with piplartine and piperine. J Appl Toxicol 28:156-163

13. Bernardo AR, Da Rocha JDB, De Lima MEF, Ricardo DD, Da Silva LHP, Peçanha LMT, Danelli MDGM (2015) Modulating effect of the piperine, the main alkaloid from Piper nigrum Linn., on murine B lymphocyte function. Braz J Vet Med 37:209-216

14. Lee YM, Choi JH, Min WK, Han JK, Oh JW (2018) Induction of functional erythropoietin and erythropoietin receptor gene expression by gammaaminobutyric acid and piperine in kidney epithelial cells. Life Sci 215:207215

15. Mounce BC, Cesaro T, Carraua L, Vallet T, Vignuzzi M (2017) Curcumin inhibits Zika and chikungunya virus infection by inhibiting cell binding. Antivir Res. https://doi.org/10.1016/j.antiviral.2017.03.014

16. Dutta K, Ghosh D, Basu A (2009) Curcumin protects neuronal cells from Japanese encephalitis virus-mediated cell death and also inhibits infective viral particle formation by dysregulation of ubiquitin-proteasome system. $J$ Neurolmmune Pharmacol:328-337

17. Kim K, Kim KH, Kim HY, Cho HK, Cheong SJ (2010) Curcumin inhibits hepatitis $C$ virus replication via suppressing the Akt-SREBP-1 pathway. FEBS Lett 584:707-712

18. Narayanan A, Kehn-Hall K, Senina S, Lundberg L, Duyne RV, Guendel I, Das R, Baer A, Bethel L, Turell M, Hartman AL, Das B, Bailey C, Kashanchi F (2012) Curcumin inhibits Rift Valley fever virus replication in human cells. J Biol Chem 287:33198-33214

19. Anggakusuma CCC, Schang LM, Rachmawati H, Frentzen A, Pfaender S, Behrendt P, Brown RJP, Bankwitz D, Steinmann J, Ott M, Meuleman P, Rice CM, Ploss A, Pietschmann T, Steinmann E (2014) Turmeric curcumin inhibits entry of all hepatitis C virus genotypes into human liver cells. Gut:631137631149

20. Mazumder A, Raghavan K, Weinstein J, Kohn KW, Pommier Y (1995) Inhibition of human immunodeficiency virus type-1 integrase by curcumin. Biochem Pharmacol 49:1165-1170

21. Neag MA, Mocan A, Echeverría J, Pop RM, Bocsan Cl, Crisan G, Buzoianu AD (2018) Berberine: botanical occurrence, traditional uses, extraction methods, and relevance in cardiovascular, metabolic, hepatic, and renal disorders. Front Pharmacol. https://doi.org/10.3389/fphar.2018.00557

22. Hayashi K, Minoda K, Nagaoka Y, Hayashi T, Uesato S (2007) Antiviral activity of berberine and related compounds against human cytomegalovirus. Bioorg Med Chem Lett 17:1562-1564

23. Li H, Li XL, Zhang M, Xu H, Wang CC, Wang S (2014) Berberine ameliorates experimental autoimmune neuritis by suppressing both cellular and humoral immunity. Scand I Immunol 79:12-19

24. Ransohoff RM, Hafler DA, Lucchinetti CF (2015) Multiple sclerosis - a quiet revolution. Nat Rev Neurol:11134-11142

25. Liu X, Zhang X, Ye L, Yuan H (2016) Protective mechanisms of berberine against experimental autoimmune myocarditis in a rat model. Biomed Pharmacother 79:222-230

\section{Publisher's Note}

Springer Nature remains neutral with regard to jurisdictional claims in published maps and institutional affiliations.

\section{Submit your manuscript to a SpringerOpen ${ }^{\circ}$ journal and benefit from:}

- Convenient online submission

- Rigorous peer review

- Open access: articles freely available online

- High visibility within the field

- Retaining the copyright to your article

Submit your next manuscript at $\boldsymbol{\nabla}$ springeropen.com 